\title{
Aminopterin/methotrexate embryofetopathy
}

INSERM

\section{Source}

INSERM. (1999). Orphanet: an online rare disease and orphan drug data base. Aminopterin/methotrexate embryofetopathy. ORPHA:1908

Aminopterin/Methotrexate embryofetopathy is a syndrome of developmental anomalies characterized by growth deficiency, facial dysmorphism and skull, limb and neural defects secondary to maternal exposure to aminopterin or methotrexate (MTX) during pregnancy. 